\title{
The Incoherence of Institutional Reform: Decentralization as a Structural Solution to Immediate Political Needs
}

\author{
Jean-Paul Faguet ${ }^{1}$ (D) Mahvish Shami ${ }^{2}$
}

Accepted: 14 September 2021 / Published online: 9 November 2021

(C) The Author(s) 2021

\begin{abstract}
Institutional reforms are structural changes in the rules and norms of authority, with effects that are long-term and unpredictable on government, politics, and society. But leaders may undertake them to solve unrelated, discrete, short-term political problems. Understanding the latter is key to understanding the characteristics of many real reforms, and hence their fate. We introduce the concept of instrumental incoherence and use it to construct a theory of decentralization where reform is motivated by orthogonal objectives. We show that reformers' incentives map onto the specifics of reform design via their side effects, not their main effects, which in turn lead to the medium- and long-term consequences eventually realized. We characterize downwardly accountable decentralization, which ties the hands of the center to empower local voters, vs. upwardly accountable decentralization, which ties the hands of local government to empower the center. We use these ideas to explain highly divergent outcomes in two extreme cases, Bolivia and Pakistan, using detailed, original evidence. Our analysis likely extends to a broader class of reforms where the incentives of agents pursuing a change, and the effects of that change, are highly asymmetric in time and dimension.
\end{abstract}

Keywords Institutions $\cdot$ Reform $\cdot$ Decentralization $\cdot$ Political incentives $\cdot$ Pakistan $\cdot$ Bolivia

Jean-Paul Faguet

j.p.faguet@1se.ac.uk

Mahvish Shami

m.shami@1se.ac.uk

1 Departments of International Development \& Government, London School of Economics and Political Science, Houghton Street, London WC2A 2AE, UK

2 Department of International Development, London School of Economics and Political Science, Houghton Street, London WC2A 2AE, UK 


\section{Introduction}

Why do political leaders undertake institutional reforms? By institutional reforms, we mean changes to the "rules of the game" (North 1990) that determine how collective decisions are taken, and resources raised and expended for public purposes. By political leaders, we mean high-level politicians, elected or de facto, with legal power to alter institutions. Why do leaders choose to modify the structures and patterns of governance by which a nation is run? Changes of this type, for example, to judicial independence, electoral systems, federal vs. unitary states, central bank independence, or presidential vs. Westminster-style executives, have deep, long-term consequences across a wide array of public and private activities, and policy areas, most of which are unforeseeable at the point of reform. That consequences should be broad and deep is implicit in the "rules of the game" concept. By contrast, leaders' incentives are famously short-term (Pierson 2004), prioritizing immediate political advantages over uncertain payoffs further in the future. The reasons for this are straightforward: in a democracy, elected politicians must win the next election or lose their jobs; in authoritarian regimes, leaders on the losing side of important transactions may see power ebb away. And yet leaders keep trying to change institutions. Why?

We propose that many institutional reforms fall into an analytical category marked by instrumental incoherence, the product of serious temporal and dimensional mismatch between the incentives of reformers and the effects of their reforms. This is broadly related to the time inconsistency problem originally analyzed by Kydland and Prescott (1977), which produced a simple but powerful insight: it can be beneficial for policymakers to announce in advance a policy they expect to influence private agents' decisions. But once private agents have made their decisions, it is in policymakers' interests to renege and act differently. Over time, private agents see that policymakers are unreliable and distrust any policy announcement. In such a context, it can be in everyone's interest to commit to a fixed policy rule at the expense of discretion. In other words, the best interests of society - and of policymakers themselves - are sometimes best served when policymakers tie their own hands. This is the crux of the argument behind, for example, independent central banking and laws prohibiting ransom payments to terrorists.

The time inconsistency insight propagated powerfully through different fields of economics during the 1970s and 1980s, and is now an accepted, well-understood part of the intellectual toolkit. ${ }^{1}$ We argue that time inconsistency is but a special case of the broader problem of instrumental incoherence, where the incentives of agents pursuing a change, and the effects of that change, are dissimilar in both time and dimension, and at the limit can be wildly asymmetric. The institutional rules we analyze typically have broader effects on politics, the economy, and society than the rules they focused on. This makes instrumental incoherence a more powerful, complex, difficult problem. Unlike inflation or the fate of hostages, institutional reform may have no agreed longterm objective. And its full effects may flow over longer time periods, implying greater uncertainty.

The problem of dimensional mismatch is important for two reasons. First, it is a more powerful source of incoherence that temporal mismatch. Politicians may, for

\footnotetext{
$\overline{{ }^{1} \text { Fischer (1980) and Lucas (1986) }}$ provide good overviews of this huge field.
} 
example, reform the electoral system from First-Past-the-Post to Proportional Representation in order to weaken an opposition party and improve their own electoral prospects. Such a change is likely to have not only short-term effects on electoral outcomes, but long-term effects as well. And the latter may well be different from the former, as the reform beds down and the behaviors of voters and politicians adjust gradually to new incentives. But electoral reform is likely to have other, broader effects in apparently unrelated dimensions such as redistribution and economic inequality (Iversen and Soskice 2006), policy stability, and the national trade regime (Rogowski 1987), to name just three potent channels.

Second, although multidimensionality is a problem for economics, it is the natural domain of political science. The mathematics of maximization makes multidimensional comparisons difficult to do with the preferred tools of economics, a point made powerfully by de Condorcet (1785). By contrast, trade-offs amongst different individuals, groups, issues, and policy areas are the bread-and-butter of political science, making instrumental incoherence more susceptible to the political scientist's toolkit.

We draw on elements of three of the most important approaches to institutional analysis in political science: game theory, historical institutionalism (Greif and Laitin 2004; Hall 2009), and more recent evolutionary approaches inspired by biology (Lewis and Steinmo 2012). ${ }^{2}$ Like historical and evolutionary institutionalists, we place the process of change at the center of our analytical frame and explain certain types of institutional change as a function of the interests and incentives of key political actors. Like game theorists, we emphasize specific actors, strategies, and benefits that explain when leaders choose a reform that is self-reinforcing, and when they do not. But our approach also diverges from these camps in important ways. Unlike them, our focus is not on gradual institutional change, but rather on sudden, voluntaristic change driven by political leaders. Rather than impersonal "change," this is better conceived of as "reform" in the sense most commonly intended by "policy reform." We stress more the long time horizons implicit in institutional reform; game theorists and historicists implicitly or explicitly assume that new institutions' payoffs will become apparent to players relatively quickly. And unlike all three schools, we stress that the outcomes of reform are highly uncertain not only in time but also in dimension, in that the class of reforms we study have effects that are not discrete and easily identifiable, but rather strikingly broad, affecting different areas of government and society.

We analyze decentralization - an important example of institutional reform that has been implemented across most of the world (Faguet 2012; World Bank 1999) through the lens of instrumental incoherence. Our contention is that decentralizations can be divided between those motivated by politicians' desire to achieve the main effects that decentralization is likely to achieve (e.g. subsidiarity) and those driven by other political imperatives distinct from such "main effects." A huge literature studies the former. Hence, we focus on the latter, far less studied class of reforms.

\footnotetext{
${ }^{2}$ Each of these is a rich body of work too large to summarize adequately here. Some additional references include the following: Game theory: Greif (1994), Mahoney and Thelen (2009), Shepsle (1989); Historical institutionalism: Levy (1999), Streeck and Thelen (2005), and Thelen (1999); and Evolutionary theories: Hodgson and Knudsen (2006), and Currie et al. (2010).
} 
Doing so turns our attention naturally to our main research question: Why does decentralization sometimes produce results orthogonal to what policy analysts might expect, and even to reformers' stated goals? To answer this, we begin with a simple prior question: Why might self-interested national leaders choose to decentralize? What drives them to effect a structural reform likely to change underlying patterns of governance in their country well into the long term? Understanding leaders' motivations will provide insight into a second key question: when leaders decide to decentralize, what drives their decision regarding how to decentralize? Stated differently: why do notionally similar reforms vary so much in their specific designs and implementation? One explanation lies in political agents' incentive structures, which map onto different decentralization designs, and hence different outcomes.

We define decentralization as the devolution of power over, and resources for, specific policies and public services to independent regional and local governments, whose officials are accountable to regional and local electorates. This is the Weberian ideal-type, from which real-world decentralizations will diverge in various ways and to different degrees. One contribution of this paper is to analyze decentralization explicitly as a deep institutional change in the structure of public authority and public finances (Eaton et al. 2018, Schneider 2003), which will have long-term effects on the following: politicians' career incentives, political parties' internal structures, the number and types of parties that can prosper in a political ecosystem, the incentives public officials face, the decisions they take, and national macroeconomic and fiscal balances, to name a few. Another contribution is to focus an analytical lens on divergence from the ideal through a detailed comparison of one case which hewed closely to the above definition vs. another that claimed to be doing something similar but actually implemented a very different sort of reform. We explore detailed, contrasting cases of decentralization in Bolivia and Pakistan. These cases are selected for the extreme differences in decentralization outcomes they display, following the method of maximum variation (or extreme case sampling; Patton 1990). The fact that Bolivia decentralized in democracy while Pakistan decentralized under dictatorship makes our comparison relevant to the many cases of both kinds of reform observed in the world. Our evidence comes from extensive fieldwork, including 30 in-depth interviews conducted in both countries, numerous local news reports, and a wide-ranging survey of relevant Pakistani and Bolivian academic literatures. To the best of our knowledge, this paper is the first to provide such detailed insight into the process of decentralization. Through interviews with policymakers - both politicians and bureaucrats - in charge of designing and implementing decentralization, we are able to highlight how the incentives and objectives of those implementing reforms were not in line with, nor accounted for, decentralization's long-term consequences in both countries.

The nature of our contribution is to bring a tacit, somewhat vague idea that "everyone knows"- politicians are not always truthful about their motives; they sometimes act according to political convenience, rather than ideology or the common good - out of the background of our thinking and place it in the center of the analytical frame. We characterize the problem such behavior creates with respect to deep institutional change. And then we analyze a specific kind of institutional change, decentralization, from the perspective of the real incentives that motivated reforms in Bolivia and Pakistan. 
The remainder of the paper is organized as follows. The "Theory" section develops an instrumental incoherence-type theory of decentralization where reform is enacted to satisfy short-term political needs. We focus on the specifics of reform design and the incentives that drive these decisions. We classify reforms as upwardly accountable vs. downwardly accountable and ask why leaders would choose one over the other? The answer, we argue, lies in the short-term political need that decentralization satisfies. The "Case Comparison" section justifies our case selection. The "Decentralization in Bolivia" and "Decentralization in Pakistan" sections employ our theory to explore the contrasting cases of Bolivia and Pakistan in fine detail. Although both opted for extensive decentralization reform, variation in regime type allows us to examine incentive structures on opposite ends of the spectrum. The "Discussion" section develops the concept of institutional incoherence further based on our empirical findings. The "Conclusion" section concludes.

\section{Theory}

Why countries decentralize at all is a surprisingly complex question. Why do leaders, having invested considerable time and resources attaining the peak of power, devolve significant portions of that power, and comparable resources, to politicians with independent mandates whom they cannot control? This is what Eaton (2004) terms "decentralization from above"; it can be thought of as intentional reform, which leaders choose, rather than being forced, to pursue. If leaders are self-interested, then decentralization from above is, on its face, absurd. It reduces the power, resources, and patronage at leaders' disposal, diminishes the standing and prestige of their office, and transforms many intended actions from straightforward command and control into exercises in negotiation. Where it happens, powerful motives must overcome the obvious incentives leaders face to keep power and resources in their hands. These motives require explanation.

Such reforms are distinct from "decentralization from below" (Eaton 2004; Eaton, Kaiser and Smoke 2011), where subnational actors force central governments to devolve greater power and resources to them. Clear historical examples include Argentina and Brazil in the 1980s, where governors succeeded in converting their power into sweeping decentralization reforms that greatly benefited them (DíazCayeros 2006; Falletti 2010; Grindle 2000), or, in a very different context, China in the 1970s and 1980s (Liu, Shih and Zhang 2018). Such decentralizations serve the interests of subnational actors, and so represent rational behavior. No additional explanation is required.

Why, then, do leaders choose to decentralize? One possible answer is a normative belief in the benefits that devolving power and resources to lower-level governments should bring. In other words, leaders' decisions may be informed by theory. Economic arguments for decentralization have a long and distinguished pedigree, going back at least to Hayek (1948) and Tiebout (1956), who argued that reform would help governments better match expenditures with citizens' needs. This happens either because information is dispersed across a country and decentralization helps governments access the information they need to take better quality public decisions (Hayek), or because citizens "vote with their feet" by moving to the locality that provides their 
preferred bundle of public services and taxes, making decentralized equilibria more efficient (Tiebout). From these ideas, Oates (1972) built the most influential public economics model of decentralization of the past 50 years, showing that decentralized provision is superior for public services that have (i) low externalities/spillovers, (ii) heterogeneous demand across space, and (iii) low economies of scale in production.

Arguments about governance and political accountability go back much further, at least to Montesquieu (1989), Rousseau (1978), Tocqueville (1994), and Mill (1993). In various forms and with different language, these authors proposed that smaller-scale governments that were more accessible to citizens would produce public decisionmaking that was more accountable and responsive to their needs. Wallis and Oates (1988) unified these arguments into the highly cited claim that decentralization can make government more responsive to local needs by tailoring public provision to the preferences of smaller, more homogeneous groups. And authors like Diamond et al. (1995), Faguet (2014a), Hechter (2000), and Horowitz (1991) extended it, arguing that a flexible decentralized government more sensitive to local demands could relieve political tensions and reduce the risk of political instability or demands for secession in diverse countries.

Unfortunately, the evidence does not support these theoretical claims. One of the first and most-cited surveys of international evidence is Rondinelli, Cheema and Nellis (1983), which found that decentralization seldom, if ever, lives up to expectations. Most of their cases reported serious administrative problems in implementation and few clear positive outcomes. A decade and a half later, surveys by Piriou-Sall (1998), Manor (1999), Smoke (2001), and Smoke et al. (2006) are modestly more positive, but with caveats about the strength of evidence in decentralization's favor. Prud'homme (1995) finds that decentralization tends to lower the quality and efficiency of public goods, aggravate elite capture of government, and worsen fiscal deficits-leading even to macroeconomic instability — via soft subnational budget constraints. Litvack, Ahmad and Bird (1998) summarize their findings thus: "It is not much of an exaggeration to say that one can prove, or disprove, almost any proposition about decentralization by throwing together some set of cases or data" (30). And Treisman's (2007) review is bleaker still, judging the evidence weak, contradictory, and inconclusive. These findings are all the more striking for being broadly based on literally hundreds of published studies in academic journals, and many hundreds more reports and evaluations by reputable national and multilateral agencies.

How can we understand such a stark disjuncture between theory and evidence? Faguet (2012) explains it as the result of three key factors: (i) an empirical confusion about "decentralization" that mixes fundamentally different reforms (e.g., deconcentration, delegation, devolution) under one rubric; (ii) problems of causal inference from small-N qualitative data (especially amongst older studies); and (iii) a dedication to simple, reduced-form questions along the lines of "Is decentralization good or bad" that overlook the essential heterogeneity implicit in the nature of this reform.

To this, Bardhan and Mookherjee add a fourth key factor in their influential book of 2006: When is decentralization properly designed and implemented, when is it not, and why? Their book is notable for concentrating on local governments, as opposed to regional or state governments, and for their focus on the political context of decentralization, showing how this shapes the evolution of reforms and its effects on equity and 
efficiency. Before appraising the effects of a decentralization, they assert, one must understand why that reform was designed in a particular way.

They lay out a threefold typology of decentralization reforms in developing countries: type A are comprehensive, big-bang political and economic devolutions (e.g., Bolivia, Indonesia); type B reforms blend comprehensive political devolution with partial, uneven economic devolution (e.g., Brazil, India); and type $\mathrm{C}$ reforms blend limited political devolution with more significant administrative and economic devolution (e.g., China, Pakistan, Uganda). The latter two categories underline that realworld decentralizations often depart from theoretical prescriptions and are not necessarily democratizing. And where decentralization is divorced from democratic participation, many of the expected benefits of reform will fail to materialize. But a properly designed and implemented decentralization, they and Bardhan (2002) point out, has the potential to widen political representation, improve government accountability, and shift public resources towards the poor. When will such decentralizations come about? Why might they be designed and implemented in this way, and when and why might they not be? The rest of this paper attempts to answer this question.

If the academic literature provides so little guidance to political leaders, why have so many of them embarked on reform? According to the World Bank (1999), an estimated $80-100 \%$ of the world's countries experimented with one or another form of decentralization since 1990. If leaders are rational and the evidence is murky, why do so many decentralize? One simple explanation is that leaders prioritize theory over evidence. They have a sincere desire to achieve the benefits that decentralization is predicted to bring about, such as improved accountability and services better-tailored to local citizens' needs. This probably explains many decentralizations across the world. But we doubt that it can explain all of them. Given the huge number of real decentralization experiments, how do we explain the rest?

The literature offers surprisingly little guidance. One important exception is O'Neill (2003), who argues that leaders decentralize when their prospects are better at the subnational level than nationally; given declining popularity, decentralization offers a reduced hold on power. Another is Dickovick (2011), who argues that leaders decentralize when their parties are weak and recentralize when they are strong. A third is Green (2010), who argues that the creation of new subnational districts can create patronage opportunities that help a ruling party stay in power. For all three authors, the impetus is declining popularity and power. These explanations are insightful. But they do not explain why leaders decentralize rather than strengthening their control at the center. Nor why non-democratic leaders decentralize. Why would leaders unencumbered by political competition choose to introduce it at subnational levels?

Our theory builds most obviously on the work of Eaton (2004), who argues that decentralization is often driven by short-term political calculations, and is a convenient means for achieving a remarkably wide range of ends; and also Boone (2003) and Levitas (2017), who analyze decentralization as a nuanced political strategy for statebuilding in West Africa and Poland, respectively. We incorporate insights from all three, as well as O'Neill and Dickovick, into a broader framework that focuses on the incentives and interactions amongst ruling and opposition parties and civil society over time, in both democratic and non-democratic settings. This framework uses short-term political needs to provide an alternative explanation for both why leaders decentralize and-especially_-how their reforms are designed. 


\section{Instrumental Incoherence}

The logic of instrumental incoherence provides a very different answer to the question: Why do politicians decentralize? It analyzes institutional reforms as structural responses to immediate political problems. The principal effects of these structural changes are realized in the long term, across different dimensions of a nation's life; they are unknown, and largely unknowable, at the time of reform. But what drives a reform are other, short-term effects, which may be orthogonal to its main effects. Taking society's broad perspective, we can think of these as the side effects of reform. The fact that politicians may consider them the main point does not alter the fact that reform's long-term, multidimensional effects will generally be of greater magnitude than its short-term, political effects. Examples of such side effects include undermining a political rival, or winning over a specific group of voters, or creating the appearance of competition in an autocracy. The details of these side effects determine how a reform is designed. The reform's design, in turn, shapes the principal, long-term effects it will have.

It may be useful to compare with everyday instrumental coherence. These are measure whose main effects are directly related to the problem a politician wishes to solve, regardless of the normative character of the latter. For example, when the goal is to improve the quality of transportation and the measure is an increase in rail or road investment, politicians are acting in an instrumentally coherent way; likewise, when the goal is to reduce political opposition to the government, and the measure involves throwing opposition leaders in jail.

Hence, incoherence lies in the instruments reformers choose, rather than the goals they seek to achieve. It is perfectly reasonable for a politician to seek to shore up a coalition or undermine a rival. And politicians' unwillingness to publicly admit to such motives may be disingenuous without being incoherent. But when they seek to achieve this through decentralization, which operates via the devolution of power and resources, and has long-term effects on government accountability, public sector effectiveness, the nature of electoral competition, political identities, and much else besides, they engage in a mismatch between the tools they use and the goals they seek that is categorical, temporal, and large. We interpret the sum of these mismatches as "incoherence in the choice of instrument for a particular job."3

Articulating a predictive theory of structural reforms that are driven by their side effects, and not their main effects, is difficult because any structural reform will have many side effects, which may themselves occur in multi-dimensional space. But doing so is necessary to construct an alternative explanation of how reform comes about. Hence, the task is to identify which side effects are most salient in the eyes of the political actors leading a reform.

To arrive at predictions, we must descend from this high level of generality and tailor our theory to the reform in question. In theory, decentralization operates by devolving power and resources to elected subnational governments (Faguet 2012). In

\footnotetext{
3 This is distinct from the additional divergences between planned vs. implemented reforms that bureaucrats and civil servants often insert into a reform process. The latter is a general phenomenon present at some level across many, if not most, developing and developed countries. Though interesting and potentially important, it is not our main focus here. Thanks to an anonymous reviewer for bringing this point to our attention.
} 
practice, as Bardhan and Mookherjee (2006), Litvack et al. (1998), and Nagarajan et al. (2015) point out, it can be done in specific ways that empower subnational governments at the expense of central governments, or empower central governments at the expense of subnational governments. The distinction is key. Reforms that devolve coherent sets of resources and responsibilities to elected subnational governments (Oates 1972) and which insulate subnational governments legally and administratively from central meddling, can be thought of as downwardly-accountable decentralizations. The resulting incentives for subnational officials are downward-pointing, via electoral accountability, to their voters (Faguet 2014a; Faguet and Pöschl 2015).

Upwardly accountable decentralizations deviate from this standard in various ways that make subnational governments beholden to the center politically, fiscally or both. Some of these deviations are empirically common, with effects that are predictable. Examples include failing to devolve real power/responsibility, or devolving insufficient resources, or making (unelected) local administrations legally or politically pervious to central commands. "Unfunded mandates" and "deconcentration" are common terms for the latter two deviations.

In brief and in relative terms, downwardly accountable decentralization shifts power away from central government to empower local officials and voters; upwardly accountable decentralization shifts power and/or resources further to the center, at the expense of local officials. ${ }^{4}$ For brevity, we refer henceforth to "downward decentralization" vs "upward decentralization." Note that in both cases, it is central government officials who choose to tie someone's hands - their own in the downward case, and local officials' in the upward case. Both kinds of hand-tying, not just the latter, help central officials achieve some specific, short-term goal.

Downward decentralization tends to be pro-competitive because it not only empowers subnational governments but also creates or empowers subnational political spaces of contestation to determine who will control devolved governments. Such decentralization changes the architecture of government not just fiscally, but by increasing the total amount of democratic contestation in a society. In this sense, it strengthens democracy (Faguet 2017; Faguet and Pöschl 2015; Schattschneider 1960).

Upward decentralizations, by contrast, tend to be anti-competitive in that they introduce specific distortions into a political system, e.g., by limiting subnational political competition, or mis-matching devolved powers and resources, or otherwise undermining the accountability of public officials to citizens. The nature of such distortions implies that upward reforms are often more convoluted and difficult for voters to understand than downward reforms. Such decentralizations may strengthen the party or leader in the short term, but tend to weaken the state in the long term because of the incoherence between what is declared and how it is justified, and what is actually achieved.

That downward decentralization strengthens electoral accountability does not imply that it is uniformly good. Decentralized systems that respect Oates' criteria but fail to

\footnotetext{
${ }^{4}$ Upward decentralization is likely to kick off a series of strategic responses and counter-responses, the net effect of which might end up benefitting either the center or the periphery. In line with the spirit of the paper, we do not attempt to solve for such extended games, and hence do not claim that the ultimate outcome of upward decentralization is beneficial to the center. But at the margin, the specific effect of, e.g., a decision to shift responsibility for services downwards while retaining resources at the center is to strengthen the center (more resources, fewer needs) and weaken the periphery (more needs, insufficient resources).
} 
incorporate equalizing transfers can result in richer districts funding better public services, while poorer areas are left to languish, exacerbating inequality and possibly stoking discontent. Under downward decentralization, voters in each district would indeed have significant control over the services provided. But their choices would not be the same.

All else equal, downward decentralization should benefit constituents more. Upward decentralization should benefit senior politicians more. Why, then, do politicians decentralize downwards? Because in their calculations, the short-term benefits of a specific reform outweigh its long-term, hand-tying costs. Such calculations may prove incorrect; politicians may overestimate their political prospects. Further analysis requires descending to the design specifics of particular reforms, which we do below.

\section{Case Comparison}

Bolivia and Pakistan may at first appear an odd choice of countries, with the former decentralizing under democracy while the latter did so under dictatorship. We argue that the comparison is fruitful for the following reasons. First, many countries have decentralized under authoritarian governments (e.g. Ethiopia, Indonesia, Russia, Tanzania). Understanding authoritarian leaders' incentives is accordingly important; it is not enough to focus only on democratic incentives. Second, both countries pursued significant, and unexpected, decentralization reforms at roughly the same time: Bolivia in 1994 and Pakistan in 2000. Both reforms were designed behind closed doors by technocrats hand-chosen by the president. And both skipped over regional governments, decentralizing straight down to municipalities. But in other ways that we explain below, the reforms were designed quite differently and had strikingly different outcomes. Focusing on cases with polar-opposite outcomes allows our study greater analytical breadth.

Lastly, Bolivia and Pakistan have other, perhaps surprising similarities that make them a particularly rich comparison. They are economically similar: per-capita GDPs of US \$5599 (Bolivia) and \$4323 (Pakistan) place both firmly in the lower middle-income category. ${ }^{5}$ Both are socially heterogeneous, with diverse populations that speak $30+$ languages in Bolivia and 20+ in Pakistan. They are geographically highly diverse, with important mountain chains, high plateaus, deserts, and tropical lowlands in both. In size, Pakistan is $771,000 \mathrm{~km}^{2}$; Bolivia is $1,100,000 \mathrm{~km}^{2}$. Both countries are chronically weak, unstable democracies that have suffered multiple coups since independence; since 1950, Pakistan has had three periods of extended authoritarian rule, and Bolivia four. And in both, decentralization was a contentious issue since the 1950s.

In the pages that follow, we describe the status quo ante in each country, and then use extensive, original field evidence to analyze the decision to decentralize as a function of very different political needs, producing predictably divergent decentralizing strategies and, hence, polar-opposite outcomes. We focus throughout on the decision to decentralize per se, as opposed to the longer-term effects of reform, and then on how the characteristics of these decisions map onto reform design.

\footnotetext{
${ }_{5}^{5}$ As categorized by the World Bank's World Development Indicators: http://data.worldbank.org/; PPP estimates for the period 1996-2000.
} 


\section{Decentralization in Bolivia}

\section{Overview}

The deep history of decentralization in Bolivia is of great contention and no decentralization. The country's Spanish colonizers bequeathed Bolivia a highly centralized public administration. In such a large, sparsely populated, diverse country, demands for decentralization were an early and regular refrain. We see this most dramatically in the 1899 civil war, in which Liberal "federalist" forces allied with indigenous militias to defeat a Conservative government that defended the unitary state. Once victory was secure, Liberals relocated the seat of government, disarmed indigenous soldiers, and executed indigenous leaders (Klein 1993). The Liberal state that followed was as centralized and hierarchical as its Conservative predecessor, only now run from La Paz. Although calls for decentralization continued throughout the twentieth century, the country's peculiar history ensured they were never answered. During its first 110 years of independence Bolivia lost half its national territory, chiefly to Chile, Brazil, and Paraguay. These traumas created a deep memory of loss, and a fear of national dismemberment that haunts Bolivians of all classes and backgrounds today. The result is a strong shared assumption amongst politicians that their country has a weak center, and national disintegration is a constant threat (Mesa 2012).

It is all the more surprising, then, that in 1994 the political establishment did an about-face and approved a radical decentralization reform that devolved significant resources and power over public services from La Paz to hundreds of municipalities throughout the country. The President who promulgated these reforms, Gonzalo Sánchez de Lozada, was re-elected in 2002. But his second term ended abruptly in 2003 when a popular uprising left many dead in the streets and he was forced to flee the country. This was followed by a period of political instability, from which Evo Morales emerged as a political giant, bestriding the national stage. First elected president in 2006, Morales won every election, plebiscite, and other electoral contest during his first decade, almost all by unheard-of margins. ${ }^{6}$ Once in office, Morales began overturning each of Sánchez de Lozada's big reforms; re-nationalizing the oil, gas, railroad, and other sectors; unpicking education reform; re-designing the executive branch; and launching new public pension and other entitlement programs. Strikingly, the one "neo-liberal" reform that Morales not only did not overturn, but instead deepened, is decentralization. First with his new Constitution, and then with a Framework Law of Autonomies and Decentralization, Morales' government expanded decentralization well beyond its initial scope, creating new levels of subnational government with new powers and privileges, and transferring far more resources to them (Faguet 2014b).

Why is this so? Surely, Morales' grip on national politics and the levers of power was sufficient to bury this reform too. Why did he instead choose to push decentralization much further and make it a centerpiece of his era? To understand this, we must understand why his arch-enemy, Sánchez de Lozada, decentralized in the first place. We must analyze how reform promised to help him overcome specific political

\footnotetext{
${ }^{6}$ His first major electoral reversal came in February 2016, when he narrowly lost a constitutional reform referendum that would have allowed him to run for a fourth presidential term, through 2025 .
} 
problems, as a function of which it was designed and implemented in very particular ways, leading to effects that proved radically different from those of Pakistan.

\section{The Problem}

Newly elected Pres. Sánchez de Lozada inherited a nation mired in economic and political malaise. Since overcoming hyperinflation in the mid-1980s, per capita income and wages had stagnated much below the pre-crisis levels of the late 1970s. Political discontent was high, with growing denunciations of government ineffectiveness and corruption. That fueled the rapid growth of neo-populist parties like the UCS (Unión Civica de Solidaridad) and Condepa (Conciencia de Patria), built around charismatic business and media tycoons, and the long-term decline of Bolivia's "traditional" political parties. By the 1990s, not even the MNR (Movimiento Nacionalista Revolucionario), the party of the 1952-1953 revolution, could win elections outright.

Meanwhile, regional pressures on central government grew. Business elites, based mainly in the fast-growing city of Santa Cruz, showed great skill in building a mass movement appealing to regional identity and pride around core business interests of greater fiscal devolution and political autonomy from La Paz. In Congress, cross-party regional blocs were able to block legislation that threatened parochial interests. And on the streets, leaders called "civic strikes" that blocked national transport links and brought major cities to a standstill, and explicitly threatened to break the country apart in pursuit of their regional demands (Sánchez de Lozada 2011, Tuchschneider 1997).

In the midst of these conflicting pressures, Sánchez de Lozada decided to decentralize. Why? The question is much more than casual. As many authors have pointed out, this is the "black hole" at the heart of the decentralization debate (Faguet 2012 and $2014 b$ ). Who gets into politics to give power away? Some have argued that decentralization was a distraction from more important items on the government's agenda, like privatization; others that it was simply "something different," tried perhaps out of a sense of desperation (Kohl 2002).

\section{The Solution}

We argue that decentralization was attractive because it offered specific solutions to pressing political problems that the new government faced. Most importantly, it offered the MNR the opportunity to forge a new covenant with the $42 \%$ of the population living in rural areas (INE (Instituto Nacional de Estadística) 1992). Rural Bolivia had been the MNR's bedrock since the Revolution, when the party redistributed land from latifundia to peasants, thereby winning the loyalty of two generations of rural voters. But by the 1990s, this second generation was dying out, and with them the powerful memory of land reform. Younger voters were defecting in droves to neo-populist parties that offered a potent mix of cultural revindication and small-scale clientelism (Sánchez de Lozada 2011, Romero 2007, Teodovitch 1997, Toro 1997).

With the Law of Popular Participation, the MNR calculated it could revolutionize government in Bolivia's large rural hinterland, traditionally poor and under-served - if not ignored-by La Paz. By creating hundreds of local governments complete with elected leaders and investment budgets for rural schools and health posts, decentralization would dramatically improve primary service provision and extend the reach of 
the state throughout the countryside (Perez 2007, Rangel 2007, Sánchez de Lozada 2011). A second "founding moment" would ensue, forging a new, multi-generational bond between the MNR and grateful rural voters. Like land reform, decentralization would make the MNR the natural party of government for another 50 years.

For similar reasons, the proposal appealed to other "traditional" political parties that were also losing votes to neo-populist upstarts (Aguirre 1997, Balcázar 1997, Brockmann 1997). The more thoughtful amongst them hoped that a new, welldesigned program of local public goods provision would undermine support for the UCS and Condepa by displacing the lure of their clientelistic gifts (Urioste 1997). Decentralization also appealed to powerful private sector interests throughout the country, who similarly feared the rise of populism (Sánchez de Lozada 2011). This included many firms in regional capitals like Santa Cruz, Cochabamba, and Tarija, which stood to gain from the boom in local construction and service contracts that rural municipalities were expected to put out to tender (and in fact did; see Faguet 2012).

The genius of Bolivia's reform was that it responded to two big problems with one instrument. It promised not only a credible cure for the MNR's long-term decline, but also a solution to regional pressures that threatened to break the country apart. Decentralization achieved the latter by acceding to the demands of regional elites, but in a way they did not expect. By decentralizing not to regional governments, which they would have dominated, but well beneath them to municipalities, Sánchez de Lozada pulled the rug out from under the business interests that had successfully mobilized so much popular support. This effectively neutralized powerful regional and civic opposition to the new government. And by going well below the level of Bolivia's major regional and ethnic cleavages, it identified decentralized governments with issues of everyday public service delivery, as opposed to regional and ethnic identity (Sánchez de Lozada and Faguet 2015). Lastly, as O'Neill (2003) and others have argued, the MNR was the best-organized party in Bolivia, with chapters in most towns and villages, and hence best placed to win local elections.

\section{The Reform}

Decentralization would cure the twin ills of hegemonic party decline and centrifugal regional pressures by administering a jolt of democracy to the Bolivian body politic. High degrees of participation in newly created local governments were essential if voters' sympathies were to be redirected from regional elites and populist parties towards the MNR. This is because fiscal weakness required significant local counterparts to help finance any significant expansion of public services (Sánchez de Lozada 2011). The Bolivian state was fiscally and organizationally weak, and needed a "citizen subsidy" to increase its presence. More importantly, an effective way to cleave citizens' sympathies away from rivals was to re-orient them towards local governments and the party responsible for creating them - not by preaching to them, but through their active participation in local governance.

The "Law of Popular Participation" had to be carefully designed if the plan was to work. Sánchez de Lozada convened a team of some 40 experts to draft the law, including members of the parties in his governing coalition, but also notable technical experts independent of all political parties (Molina 1997). The group worked behind closed doors debating how best to design a decentralization that effectively devolved 
power and increased the participation and responsibility of citizens. Many versions of the law were produced and debated; as the project took shape, more advanced drafts were discussed with opposition parties and interest groups (Sánchez de Lozada 2011, Tuchschneider 1997).

Initial drafts decentralizing to regions, as regional elites had long demanded, were rejected. Then, the group hit upon the idea of decentralizing to elected municipal governments, and leaving unelected, weak administrations in regional capitals. This solved the problem of devolving real power and resources and increasing citizen participation without adding fuel to the secessionist fire. It also, very cannily, disempowered Santa Cruz' business elites (Molina 2007, Sánchez de Lozada 2011). The reform was strikingly simple, straightforward, and easy to comprehend. Its five main points were:

1. Ownership of infrastructure in, and responsibility for provision of, primary services - primary education, health, local transport, etc.-were transferred from central to local governments.

2. Twenty percent of national tax revenues were transferred to municipalities.

3. Funds were allocated amongst municipalities on a strict per capita basis.

4. Enhanced accountability was built into the law via Oversight Committees, which incorporated natural civic organizations (e.g., peasant unions, neighborhood committees, ayllus) into municipal governance.

5. New municipalities were created, and existing ones expanded, to incorporate all of Bolivia into the system. Border adjustments were carried out by local consensus.

Oversight Committees (OCs) were meant to incorporate Bolivia's diverse, spontaneous civic organizations into the local governance framework. To this end, the OC and its President enjoyed legal equivalence with the Municipal Council and Mayor, such that the OC could suspend central transfers to the municipality if they disagreed with local investment or policy priorities.

The initial reaction to reform was, with hindsight, funny. Labor leaders united with business elites and NGOs to denounce the "damned law", and organized protest marches in Bolivia's main cities. But eager take-up by citizens, including a $127 \%$ rise in voter turnout, plus massive participation in participative planning and grass-roots accountability mechanisms in Bolivia's towns and villages (Faguet 2012), gave the lie to claims that this was yet another tool of "neoliberal domination." Within Bolivia, this line of attack was swiftly abandoned.

Curiously, the idea that decentralization was a neoliberal imposition of the World Bank and other international agencies has continued to resonate outside Bolivia, especially amongst the NGO and activist communities (e.g., Hylton and Thompson 2007; Kohl and Farthing 2006). Faguet (2012) and Sánchez de Lozada and Faguet (2015) forensically analyze the decision to decentralize Bolivia, and then the process of designing the reform. Not only were the World Bank and others not involved, during the first 2 weeks after its announcement, they failed to recognize Popular Participation as the decentralization program it clearly was. ${ }^{7}$ Bolivian reformers employed a language and administrative structure-incorporating indigenous organizations and decentralizing to municipalities

\footnotetext{
7 In response to "Was decentralization a World Bank imposition?", Sánchez de Lozada exclaimed, "Oh, they did not have the slightest idea!' (Sánchez de Lozada and Faguet 2015, 48).
} 
instead of regions - that significantly departed from the "international best practice" blueprints recommended by international financial institutions at the time. This indigenization of reform probably explains their initial confusion.

Decentralization's effects on public sector investment patterns were immediate, dramatic, and nationwide. Resources shifted from a small number of rich districts to Bolivia's smaller, poorer, rural, traditionally abandoned municipalities. The Bolivian state became more responsive to local needs through the actions of its municipalities (Faguet 2012 and 2014b). And so decentralization became a normal way of life for Bolivians, and eventually a defining national characteristic, as it remains today. Not even the political earthquake that overthrew Sánchez de Lozada's second presidency some years later, and buried the entire political establishment, could undo this reform.

During his first years in office, Morales reversed all of Sánchez de Lozada's reforms in a deliberate, highly symbolic fashion. He also began quietly recentralizing resources and authority from departments and municipalities to La Paz. But demands from the regions - and, more powerfully, from Bolivia's villages and towns - convinced him to change course. Opposition to the government's centralizing tendencies led to violent confrontations in 2007-2008, and the deaths of anti-government protesters. This, in turn, paralyzed the constitutional reform process-Morales' signature policy-amid mounting rumors of armed militias and the threat of civil war.

Morales' canny solution took a leaf out of Sánchez de Lozada's book. With quiet irony, the government changed tack and proposed further devolution to elected regional governments - no longer appointed administrations - as well as the creation of new layers of provincial-level government, and new types of rural and indigenous autonomy. Central resource transfers increased significantly. This combined tactic allowed Morales to claim credit for a new reform, christened Autonomías, that was distinct from Sánchez' decentralization. The highlights of this about-face fit nicely into Morales' broader discourse of indigenous politics and more resources for rural areas.

\section{Decentralization in Pakistan}

\section{Overview}

In 1999, on a return flight from Sri Lanka to Pakistan, Chairman of the Joint Chiefs of Staff General Pervez Musharraf was informed that Prime Minister Nawaz Sharif had removed him from office and barred his flight from landing in Pakistan. Incensed, Musharraf ordered his generals, through Dubai Air Traffic Control, to take control of Karachi Airport. The flight landed with $7 \mathrm{~min}$ of fuel remaining. ${ }^{8}$ Musharraf immediately ordered the arrest of Sharif and his closest collaborators, and dissolved the national and provincial assemblies. On 12th October 1999, Gen. Musharraf took over as Chief Executive, acting, he claimed, from "sincerity, loyalty and selfless devotion to the country," as corrupt politicians had rendered civilian institutions dysfunctional. ${ }^{9}$

\footnotetext{
${ }^{8}$ A scheduled Pakistan International Airlines flight, with 200+ passengers aboard. http://www.nytimes.com/ 1999/10/17/world/countdown-to-pakistan-s-coup-a-duel-of-nerves-in-the-air.html?ref=pervezmusharraf

${ }^{9}$ http://www.pakistani.org/pakistan/constitution/post_12oct99/musharraf_address_13oct1999.html
} 
A Supreme Court ruling gave Musharraf 3 years in office, after which he must restore democracy. ${ }^{10}$ The military government seized this opportunity to introduce a third tier of local government below provincial governments. The reform was drafted by the National Reconstruction Bureau (NRB) and approved in March 2000, with elections scheduled for August 2001. Seven years later, before a third round of elections, Musharraf was forced to resign. One of the first acts of the new democratic government was to cancel local elections and recentralize power to the provinces. Why was decentralization abolished so soon after the restoration of democracy? And why did no Pakistani fight to retain a system that brought government closer to them? Answers to these questions, we argue, lie in the political motivation that drove the enactment, design and implementation of reform.

\section{The Problem}

Pakistan's third military dictator came to power following its longest and most turbulent stretch of democracy, during which power switched hands repeatedly between arch-rivals Benazir Bhutto and Nawaz Sharif. Both had come to power twice, and both had been ousted (constitutionally) half-way through their terms on charges of corruption. Perhaps tired of instability, the public did not protest Musharraf's coup; many hoped government might improve (Waseem 2006).

How could Musharraf legitimate his de facto regime and prolong his time in power? He formed an anti-corruption unit that systematically targeted political opponents in an aggressive witch-hunt, while ignoring evidence against pro-regime politicians (Waseem 2006). Those charged were often acquitted if they switched allegiance to the pro-regime political party (Pakistan Muslim League - Q). This had the dual effect of demonizing the political class as fundamentally corrupt and bolstering a party that supported the dictatorship.

But to remain in power, it was not enough to prosecute the opposition. Failure to comply with the court's 3-year deadline would seriously undermine Musharraf's legitimacy. This was underlined by pressure from the international community, as well as a free and critical media at home. In a bid to gain public support, Musharraf called a referendum proposing himself as President, with elected national and provincial governments. But how could a man who had overthrown a democratically elected government win a referendum? Where would he find the grass-roots support necessary to prolong his regime?

\section{The Solution}

Musharraf found his answer in decentralization (Talbot 2012). The new tier of local government would create some 80,000 offices, whose occupants, and their dependents, would be directly beholden to him. These would be the foot-soldiers of a political movement that would win the referendum and keep him in office. And it had the added advantage of placating the international community in the wake of a coup, as it signaled a first step towards democratization. Although the conception and design of the reform were highly idiosyncratic, as explained below, organizations such as the World Bank,

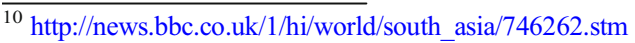


Asian Development Bank, USAID, DFID, and others quickly offered to aid the initiative (Manning et al. 2003).

Reform was officially marketed as deepening democracy. But as one informed observer notes, "it was clear to everyone that the system was being implemented to legitimize Musharraf's military rule" (Sultan 2013). The reform was carefully crafted to achieve this in its planning, implementation, and design stages. A Local Government Ordinance (LGO) was drafted and implemented by the NRB, a collection of top military personnel and pro-regime bureaucrats and politicians headed by a general. Members of the main political parties were explicitly excluded, depriving the process of inputs from seasoned politicians and poisoning any sense of ownership some may have felt towards the idea. According to Shafqat Mehmood (2015), a senior Pakistan Tehreek-e-Insaf politician, the NRB's composition further crippled the process, as they "had no idea about social ethos and political reality. They approached it like a military structure, erecting lines of power and hierarchy in a manner that works in the army. The result was the creation of positions that no one understood."

The LGO was passed in March 2000, 6 months after the coup. Musharraf's plan required local government to be functioning before the April 2002 referendum. Hence, local elections were called in August 2001. As provincial governments would not be reconstituted until the October 2002 general election, powers and resources were devolved from the provinces to newly created local governments before new provincial governments could take office. And no compensating powers were transferred to provinces from the center (Cyan et al. 2004). The latter makes Pakistan an odd outlier in the international context, where most devolved powers and resources previously lay with central government (Faguet 2012). The provincial governments that came to power in 2002 found much-depleted versions of their offices. They were further constrained by special presidential protections given to local governments, eliminating provinces' constitutional right to alter or abolish them during two terms (Talbot 2012). Not surprisingly, relations between provincial and local governments were antagonistic from the start.

\section{The Reform}

Tensions might have been lessened if decentralization had awaited the restoration of democracy in 2002 (Yousafani 2015). But reformers' priority was not to design wellfunctioning democratic institutions, but rather to win a referendum. Several of the reform's clauses explicitly prevented the former: (a) the systematic exclusion of political parties, (b) the convoluted design of the system, and (c) a weak and unclear link with provincial governments. Unconsulted during the planning stage, established political parties were explicitly excluded from the local governments that emerged. The public justification was parties' corruption. The purpose of local government, exChairman of the NRB Gen. Tanveer Naqvi (2015) explained, was to lay the infrastructure for democracy. Exclusion was required to allow new blood into the system, reformers argued, so that "true democracy" could flourish. Such views were probably sincerely held by at least some reformers. More practically, a regime that had just ousted the parties wanted no dealings with them. But the most important motivation was Musharraf's need for a political constituency (Sultan 2013). Partisan elections 


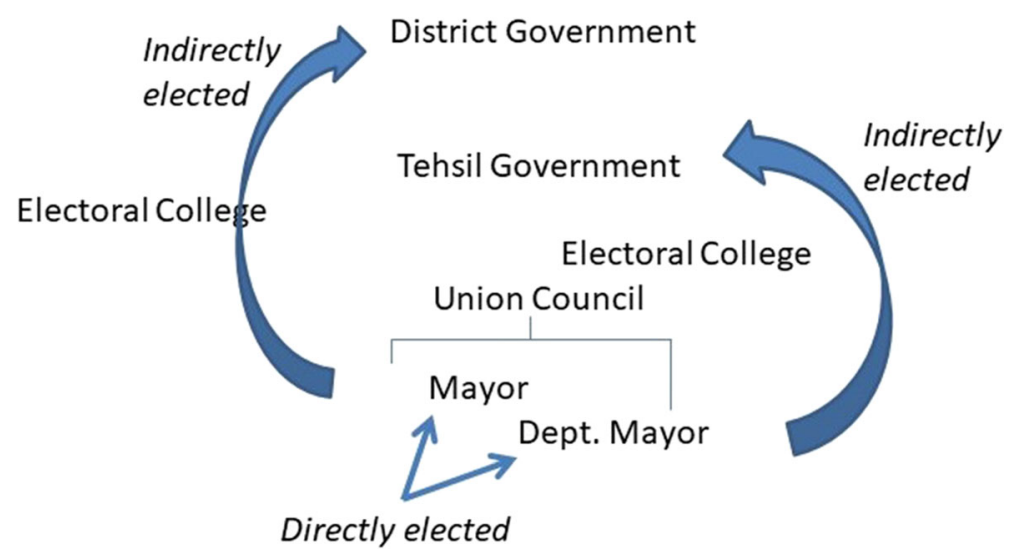

Fig. 1 Links between different tiers of local government. Source: Adapted from Cheema and Mohmand (2008)

would likely elevate anti-Musharraf politicians to office, risking defeat in his referendum.

To further protect the regime's interests, the reform stipulated limited direct elections and extensive indirect elections. Amongst its three tiers - district, tehsil (municipality), and union-only the lowest, union tier was directly elected, which then formed the electoral college for district and tehsil governments (see Fig. 1). ${ }^{11}$ But most decisionmaking authority, particularly over resources, lay with district governments. Thus, directly elected officials had little say in the planning and implementation of projects (Keefer et al. 2003). The official justification for indirect elections was to maintain an equal-size electoral college (Waseem 2006). But according to Daniyal Aziz (2013), NRB ex-Chairman, the driving factor was actually fear that "...if you had direct elections, then real politicians would come up and sort out Musharraf."

Limiting direct elections ensured that the "new blood" entering politics had limited upward mobility. The institutionalization of politics and political parties was undermined, and elections were turned into beauty contests where individuals ran for office based on charisma and influence rather than issues. Subnational politics was blighted by patronage and vote buying (Waseem 2006). Lastly, non-party elections excluded lower and middle-class candidates, who lacked the resources to stand for office without party backing. Where democratic participation is an objective, simplicity of design underpins success by making reform understandable to ordinary citizens. But complexity and non-transparency could be advantageous if the main aims were to undermine political elites and legitimate the dictator. Accordingly, Gen Naqvi was given free rein to decentralize Pakistan in a way functional to the regime's goals (Mehmood 2015).

Convolution and complication were made worse by the lack of hierarchical, fiscal, or political linkages between the three tiers of government. This was by design (Manning et al. 2003). Each tier operated independently, resulting in poor coordination and limited oversight (Taj 2010). It was intended that oversight be exercised by citizens

\footnotetext{
${ }^{11}$ Gen. Naqvi, architect of the reform, opposed indirect elections, which he feared would lead to patronage and vote-buying. Despite his objections, the final version of the reform had direct elections for the lowest tier.
} 
through Village and Neighborhood Committees (VNCs), formal bodies involved in planning and budgetary processes similar to Bolivia's Oversight Committees. But in most unions, VNCs were never established, and citizens did not know what they were (Manning et al. 2003). Their absence, combined with indirect elections, greatly hindered the accountability of higher tiers of government.

Accountability was further undermined by murky demarcations of responsibilities between hierarchical layers. For example, hospitals were devolved to district governments, but teaching hospitals remained under the purview of provincial governments (Manning et al. 2003). High levels of illiteracy and citizens' limited democratic experience made most unaware of whom to approach for their needs, or whom to hold responsible for poor service provision.

The last, and probably biggest, constraint to local government efficiency-and ultimately its survival - was the link created between provincial and district governments, depicted in Fig. 2. District government was designed to be hierarchically below provincial government. But the LGO gave district mayors authority to override provincial chief ministers, effectively making them independent of, or even superior to, provincial heads (Cyan et al. 2004). Such provisions ensured that district officials remained loyal to Musharraf, but created resentment from incoming provincial governments.

Many powers devolved to local government concerned highly visible, laborintensive services such as health, education, and agriculture. These were some of the main sources of patronage, further exacerbating tensions between provinces and districts (Aziz 2013). Worse still, the reform required provincial governments to transfer funds to district governments, as the latter had few revenue-generating capabilities of their own (Taj 2010). The system further called for abolition of the ruralurban divide in resource allocation. Intended to facilitate rural development, this change drained cities of needed funds. In a political system characterized by patronage politics,

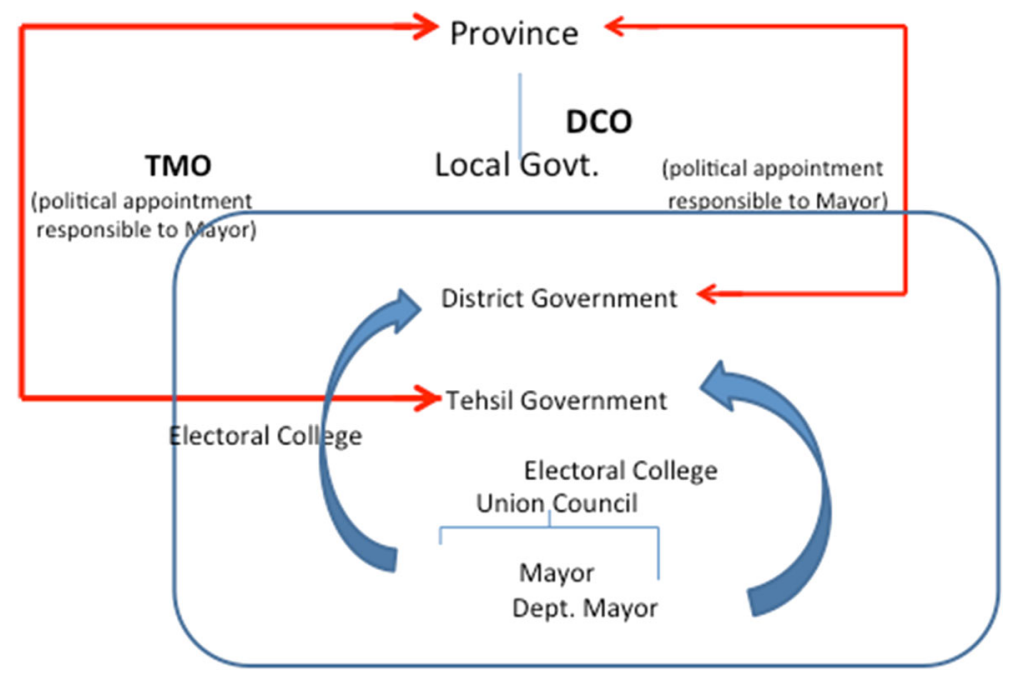

Fig. 2 Lines of reporting and accountability amongst levels of government. Source: Adapted from Cheema and Mohmand (2008) 
local government was now seen as a threat to provincial politicians' ability to mobilize their base (Cyan et al. 2004).

Realizing the need for coordination between levels, the NRB created District Coordination Officers (DCOs) - appointed bureaucrats - to facilitate communication between provincial and district governments. But DCOs were chosen by provincial governments, which had authority to transfer them at any time (Taj 2010). This placed DCOs in the awkward position of being responsible to district governments but accountable to the provinces (Hasan 2002). In practice, it was the party affiliations of provincial and district officials that determined how these relationships functioned. In districts where mayors belonged to the party of the provincial government, relations were relatively smooth. As Mian Amir (2013), ex-District Mayor of Lahore, explained, "I never had money problems as I was part of the government [political party]." Problems arose when a mayor belonged to the opposition. Not only did provinces delay their funds, but any DCO cooperating with district mayors was transferred, making it difficult for mayors to implement policies.

Politicians were not the only group that resented the local government system. Bureaucrats, too, were provoked when they found their authority curtailed. Prior to 2001 , districts were run by deputy commissioners. Staffed by a bureaucrat, this office was in charge of most district policy-related issues. The LGO abolished the position, handing its powers to mayors, and replaced it with comparatively weaker DCOs, who had limited rent-seeking opportunities (Taj 2010, ul Haq 2015).

It is hardly surprising that a reform generating tensions between district and provincial governments, ill-will from bureaucrats, and the opprobrium of politicians was quickly reversed by the opposition upon regaining power. By design, the reform excluded political parties, and so was incompatible with their interests. Since the dictatorship had focused so much on undermining the opposition, and so little on enhancing citizen welfare, common Pakistanis perceived little benefit from local government. They saw no need to oppose re-centralization. In 2008, 7 years after its introduction, decentralization was quietly abolished in Pakistan.

\section{Discussion}

In Pakistan, Gen. Pervez Musharraf had stumbled into power more or less unexpectedly. His problem was to legitimize his dictatorship in the public's eye, and then extend his rule beyond the 3 -year transition conceded by the Supreme Court. He and his circle hit upon a structural solution: decentralization to newly created local governments, which might in principle have extended the reach of the state deep into the Pakistani hinterland, provided some services, and made citizens feel the government shared their concerns.

But the nature of the immediate problem-legitimizing a regime that had overthrown an elected government-required disempowering Pakistan's political parties. Additionally, Musharraf's tenuous legal position, and his uncertain command of the bureaucracy, implied an overriding need to consolidate power and authority and avoid further dramatic change. The decentralized structure that emerged should not be capable of moving quickly or acting decisively. These imperatives explain the two key characteristics of Musharraf's decentralization: (i) the explicit exclusion of 
Pakistan's political establishment, and (ii) a convoluted architecture defined by ambiguity in service responsibilities, obtuse reporting, and circuitous fiscal flows. Together, these produced weak, confused accountability, and low levels of participation and legitimacy amongst ordinary Pakistanis. Such a decentralization lacked mechanisms of institutional reinforcement (Greif and Laitin 2004). It earned little support from the grass-roots of Pakistani society, and massive opposition from the parties.

In Bolivia, by contrast, the President faced key challenges deeply embedded in democratic contestation. His party, the "natural party of government," was in long-term decline. It could no longer win elections outright, and found it increasingly difficult to assemble governing coalitions with Bolivia's other "traditional" parties, themselves suffering similar processes of decay. The root of their difficulties lay in the rise of neopopulist parties that prospered by attacking corruption, patronage, and the political elite. Additionally, a second set of pressures threatened to stop the government in its tracks: business elites in Santa Cruz and other Eastern regions aggressively threatened secession, and manipulated regional identity to extract resources and policy concessions from La Paz. Like Gen. Musharraf, Pres. Sánchez de Lozada hit upon a structural solution: decentralization to newly created local governments, which would extend the reach of the state deep into the Bolivian hinterland, provide primary services, and make citizens feel the state cared for them.

Like Pakistan, the nature of the immediate problem dictated the terms of Bolivia's solution. But there the comparison ends. Sánchez de Lozada sought to treat the twin ills of political decay and secessionism by administering a jolt of democracy. He sought to win back voters' loyalty by suddenly and radically increasing their participation in government via the hundreds of municipalities he created up and down the country. If it was to work, voters would have to believe in these new local governments. If it was to last, voter behaviors must change and political elites must be coopted. These imperatives explain the three key characteristics of Bolivian reform: (i) devolution of significant resources and decision-making power from central to local government; (ii) an unusually simple and transparent architecture defined by direct fiscal flows, clear service responsibilities, and straightforward reporting; and (iii) the unambiguous buyin of the political establishment. These details were widely disseminated throughout the country. Together, they generated strong accountability and high levels of political participation.

It is telling that in both countries, reform was driven by internal political needs that leaders viewed as immediate priorities. Both Sánchez de Lozada and Musharraf were aware that their decentralizations would be smiled upon by key foreign governments and multilateral institutions. But in both cases, the decision to decentralize, and - more importantly - the many intricate details of program design and implementation, were determined behind closed doors by small groups of key advisers. Reformers worked in consultation with a few key political and business interests in Bolivia, while in Pakistan they worked alone. In both cases, the language of the reforms and their highly idiosyncratic fiscal and legal characteristics bear witness to a preoccupation with local political imperatives and a striking absence of external influence.

Our theory predicts that a downward decentralization, designed to expand and intensify political competition, will strengthen democracy and so survive changes in government. This proved true in Bolivia. The legitimacy local governments quickly earned with ordinary citizens produced a massive groundswell of support for Bolivian 
Table 1 Summary of empirical sketches of decentralization (see annex 1)

\begin{tabular}{|c|c|c|c|c|c|c|}
\hline & Case & Problem & Solution & Result & Population* & $\begin{array}{l}\text { A r e a } \\
\left(\mathrm{km}^{2}\right)^{*}\end{array}$ \\
\hline 1 & $\begin{array}{l}\text { Uruguay, } \\
1870 s \& \\
1890 s\end{array}$ & $\begin{array}{l}\text { Civil conflict, } \\
\text { militia uprising, } \\
\text { skewed } \\
\text { distribution of } \\
\text { power across } \\
\text { space }\end{array}$ & $\begin{array}{l}\text { Decentralization to } \\
\text { departments, with } \\
\text { joint selection of } \\
\text { subnational officials }\end{array}$ & $\begin{array}{l}\text { Rebellions ended. } \\
\text { Nationwide } \\
\text { power-sharing be- } \\
\text { tween rural Blanco } \\
\text { and urban Colora- } \\
\text { do parties institu- } \\
\text { tionalized }\end{array}$ & 3.5 million & 176,215 \\
\hline 2 & $\begin{array}{l}\text { South Africa } \\
1990 s\end{array}$ & $\begin{array}{l}\text { Expected electoral } \\
\text { extermination of } \\
\text { National Party } \\
\text { post-Apartheid }\end{array}$ & $\begin{array}{l}\text { Decentralization to } 3 \\
\text { subnational tiers of } \\
\text { government }\end{array}$ & $\begin{array}{l}\text { Creation of regional } \\
\text { fiefs for National } \\
\text { Party and Inkatha } \\
\text { Freedom Party. } \\
\text { Peaceful transition } \\
\text { to democracy }\end{array}$ & 58.6 million & $1,219,090$ \\
\hline 3 & Brazil 1970s & $\begin{array}{l}\text { Stabilizing a de } \\
\text { facto regime }\end{array}$ & $\begin{array}{l}\text { Decentralization to } \\
\text { states. Political } \\
\text { opening in which } \\
\text { national } \\
\text { authoritarianism } \\
\text { coexists with } \\
\text { subnational } \\
\text { competitive elections }\end{array}$ & $\begin{array}{l}\text { Military regime } \\
\text { stabilized; lasts } \\
\text { longer than any } \\
\text { other in the region }\end{array}$ & 211 million & $8,515,770$ \\
\hline 4 & $\begin{array}{r}\text { Uruguay } \\
1990 \mathrm{~s}\end{array}$ & $\begin{array}{l}\text { Keeping upstart } \\
\text { FA-EP out of } \\
\text { power }\end{array}$ & $\begin{array}{l}\text { Local elections } \\
\text { de-linked from na- } \\
\text { tional elections; } 2 \text { nd } \\
\text { round introduced }\end{array}$ & $\begin{array}{l}\text { Traditional parties } \\
\text { retain duopoly. } \\
\text { Subnational } \\
\text { officials gain } \\
\text { stature at expense } \\
\text { of national leaders. } \\
\text { Party discipline } \\
\text { weakened }\end{array}$ & 3.5 million & 176,215 \\
\hline 5 & Chile $1990 s$ & $\begin{array}{l}\text { Counteract } \\
\text { systematic } \\
\text { disadvantages } \\
\text { for Left parties } \\
\text { in post-Pinochet } \\
\text { constitution }\end{array}$ & $\begin{array}{l}\text { Democratization of } \\
\text { previously appointed } \\
\text { local governments }\end{array}$ & $\begin{array}{l}\text { Left initially wins } \\
\text { most local } \\
\text { elections. But then } \\
\text { Right becomes } \\
\text { adept at winning } \\
\text { local elections, and } \\
\text { is soon } \\
\text { overrepresented in } \\
\text { municipal } \\
\text { governments }\end{array}$ & 19 million & 756,102 \\
\hline 6 & $\begin{array}{c}\text { Venezuela } \\
1980 s\end{array}$ & $\begin{array}{l}\text { Shoring up power } \\
\text { base of new } \\
\text { president who is } \\
\text { unpopular with } \\
\text { party leaders }\end{array}$ & $\begin{array}{l}\text { Decentralization to } \\
\text { directly elected } \\
\text { regional and local } \\
\text { governments }\end{array}$ & $\begin{array}{l}\text { Rapid spiral of decline } \\
\text { of traditionally } \\
\text { dominant AD and } \\
\text { COPEI parties. } \\
\text { Increasing political } \\
\text { instability and rise } \\
\text { of Hugo Chavez }\end{array}$ & 28.5 million & 912,050 \\
\hline 7 & $\begin{array}{l}\text { Argentina } \\
\text { Repea- } \\
\text { tedly } \\
\text { during } \\
\text { nineteenth } \\
\text { and } \\
\text { twentieth } \\
\text { centuries }\end{array}$ & $\begin{array}{l}\text { Many transient } \\
\text { political } \\
\text { problems }\end{array}$ & $\begin{array}{l}\text { Many temporary } \\
\text { agreements } \\
\text { regarding resources } \\
\text { and power-sharing } \\
\text { between center and } \\
\text { periphery }\end{array}$ & $\begin{array}{l}\text { Cycles of } \\
\text { decentralization and } \\
\text { recentralization. } \\
\text { Uninstitutionalized, } \\
\text { unstable } \\
\text { revenue-sharing } \\
\text { system that is sub- } \\
\text { servient to momen- } \\
\text { tary political imper- } \\
\text { atives. The absence } \\
\text { of structure in }\end{array}$ & 45 million & $2,780,400$ \\
\hline
\end{tabular}


Table 1 (continued)

\begin{tabular}{|c|c|c|c|c|c|c|}
\hline & Case & Problem & Solution & Result & Population* & $\underset{\left(\mathrm{km}^{2}\right)^{*}}{A \text { r e a }}$ \\
\hline & & & & $\begin{array}{l}\text { service to continual- } \\
\text { ly changing political } \\
\text { needs }\end{array}$ & & \\
\hline 8 & $\begin{array}{c}\text { Ghana } 1980 s \\
\text { \& 1990s }\end{array}$ & $\begin{array}{l}\text { Destroying the } \\
\text { political power of } \\
\text { rural elites and } \\
\text { taxing their } \\
\text { economic activity }\end{array}$ & $\begin{array}{l}\text { Decentralization with } \\
\text { top-down control, } \\
\text { and local account- } \\
\text { ability short-- } \\
\text { circuited, to build a } \\
\text { centralized local state }\end{array}$ & $\begin{array}{l}\text { Sham "paper } \\
\text { decentralization," } \\
\text { in name only }\end{array}$ & 30 million & 238,533 \\
\hline 9 & $\begin{array}{l}\text { Côte d'Ivoire } \\
1990 s\end{array}$ & $\begin{array}{l}\text { Extending presence } \\
\text { of the state } \\
\text { without allowing } \\
\text { local-level points } \\
\text { of access to state } \\
\text { resources. } \\
\text { Preventing emer- } \\
\text { gence of new } \\
\text { leaders in the re- } \\
\text { gions }\end{array}$ & $\begin{array}{l}\text { Decentralization via } \\
\text { deconcentrated, } \\
\text { minimal, } \\
\text { military-style admin- } \\
\text { istrative corps direct- } \\
\text { ly controlled by cen- } \\
\text { tral government }\end{array}$ & $\begin{array}{l}\text { Sham "paper } \\
\text { decentralization," } \\
\text { in name only }\end{array}$ & 25.7 million & 322,463 \\
\hline 10 & $\begin{array}{c}\text { Tanzania } \\
1970 \mathrm{~s}\end{array}$ & $\begin{array}{l}\text { Greater planning and } \\
\text { control of local } \\
\text { affairs to facilitate } \\
\text { implementation } \\
\text { of central } \\
\text { directives }\end{array}$ & $\begin{array}{l}\text { Decentralization by } \\
\text { extending central } \\
\text { government } \\
\text { downwards, with } \\
\text { top-down control. } \\
\text { Replacing elected } \\
\text { councils with } \\
\text { centrally-appointed } \\
\text { authorities }\end{array}$ & $\begin{array}{l}\text { Sham } \\
\text { decentralization. } \\
\text { Rationalization } \\
\text { and consolidation } \\
\text { of central } \\
\text { government } \\
\text { control }\end{array}$ & 58 million & 947,300 \\
\hline 11 & Chile $1920 s$ & $\begin{array}{l}\text { New dictator's wish } \\
\text { to undermine } \\
\text { civilian political } \\
\text { parties }\end{array}$ & $\begin{array}{l}\text { Replacement of } \\
\text { elected local } \\
\text { governments with } \\
\text { appointed } \\
\text { authorities }\end{array}$ & $\begin{array}{l}\text { Undermining } \\
\text { decentralization } \\
\text { and democracy. } \\
\text { Increasing } \\
\text { centralization }\end{array}$ & 19 million & 756,102 \\
\hline
\end{tabular}

* Sources: World Bank Open Data; CIA World Factbook

reform (Hiskey and Seligson 2003). Unlike Pakistan, institutional reinforcement in Bolivia was high. This explains why Morales, who reversed all of Sánchez de Lozada's other reforms, ended up decentralizing greater powers and more resources to lower levels of government.

How strikingly different from Pakistan, where a reform that was obtuse and confusing failed to win the trust of the people but succeeded in earning the contempt of elites. Our theory predicts that upward reforms like Pakistan's, designed to distort political competition and undermine accountability, are more likely to perish. Evidence from Pakistan bears this out. When Musharraf was forced to resign in 2008, one of the first acts of the democratic government that replaced him was to abolish his decentralization. Local government died a quiet death in Pakistan, in full view, lamented by no one.

Broader evidence from Africa and Latin America, presented in annex 1 as 11 empirical sketches, and summarized in Table 1, supports our analysis. Our evidence 
shows, first, that decentralization has been pursued in a wide variety of contexts: from small populations in small territories through to large populations in huge territories; under dictatorships and democracies; and during both war and peace. It underlines that for decentralization to proceed, the problem in question must be immediate and pressing. But it need not concern space nor government hierarchy. It can be as orthogonal to decentralization as excluding an upstart rival from national elections, stabilizing a dictatorship, or countering the institutional manipulations of a previous dictator. In all such cases, reform has long-term effects on politics and the state that are deep, sometimes unwanted, and always unexpected. These quick empirical sketches suggest that our core insight travels beyond Pakistan and Bolivia, and may have relevance for a wide variety of countries.

\section{Conclusion}

Why do leaders decentralize? Who spends the better part of a career, and often a lifetime, climbing the greasy pole of power, only-having reached the apex-to devolve power and resources to subnational officials with independent mandates whom they cannot control? Who gets into politics to give power away? This is one of two "black hole" problems at the heart of the decentralization debate. The second is: Why do apparently similar decentralization reforms often produce strikingly different outcomes, some of which are at odds with reformers' stated objectives?

We offer a new explanation that can help answer both questions. Many decentralizations are no doubt motivated by the expected benefits of devolving power and resources. But in a large share of cases, we contend, politicians decentralize in order to solve specific, discrete, often short-term political problems. Our analysis very likely extends to a much broader class of deep institutional reforms with long-term consequences. Normative appeals to efficiency, state effectiveness, or the common good may excite some leaders but are unlikely to move others to undertake costly reforms. For the latter, self-interested politicians to expend the energy and political capital implied in assembling the coalitions required to push through significant reforms to the architecture of government, it must be the case that the costs of reform are outweighed by specific benefits.

The crucial point is that decentralization is not a specific, short-term, or discrete policy measure. It is, rather, a deep change in the structure of public finances and authority with long-term effects on: the incentives public officials face, the decisions they take and policies they implement, national fiscal balances, macroeconomic stability, the spatial distribution of economic activity, politicians' career incentives, and political parties' internal structures, to name a few. Decentralization changes how a country is run, and so can be expected to have deep effects on many dimensions of a country's life well into the long term.

As the case studies above showed, decentralization reforms are often not designed around such factors. The key to understanding when and how these countries decentralized is, rather, as solutions to pressing, well-defined political problems. Understanding these problems helps further our understanding of the different kinds of decentralization countries implement, as well as their effects. It is important to note that incoherence $\neq$ bad in our analysis. Even reforms designed in instrumentally 
incoherent ways can have positive long-term effects. We see this in Bolivia, where reform failed in its instrumental intent (the MNR did not return to dominance), but democracy deepened, political accountability improved, participation increased notably, and a more complex, multi-level state better suited to Bolivia's complex, heterogenous society was consolidated.

More generally, many politicians seem to find institutional reform irresistible, even though the effects of such reforms are unpredictable, multi-dimensional, and likely to extend into the long term. Consider the geographic spread, and deep potential implications, of some recent examples both big and small: reforms to judicial independence in Poland and the UK; Sri Lanka's transition from a presidential to a parliamentary system; the creation of new states in India and new districts in Uganda; reforms to the electoral systems of Bolivia, Chile, Israel and New Zealand; the Brexit referendum and the UK's fractious withdrawal from the European Union; and decentralization in countries as diverse as Colombia, France, India, Japan, Mexico, Mozambique, Serbia, and South Korea (to name a few).

Or rather, perhaps the unpredictability of reform's effects is precisely what appeals? Politicians can promise voters that far-reaching changes to the institutions that govern them will yield broad benefits, while implementing measures actually designed to solve specific, immediate problems of their own. From society's point of view, these last can be thought of as the side-effects, and not main effects, of reform - which we argue are nonetheless determinant. The uncertainty and complexity surrounding reform's real effects work strongly in politicians' favor, undermining even informed predictions, and making voters' expectations easier to manipulate. The result is a sort of institutional reform engine, in which reforms are justified in terms of broad objectives A, but are designed to achieve narrow objectives $\mathrm{B}$; and their effects in the long run may belong to a third, largely unknown, set $\mathrm{C}$ (which may, or may not, contain elements of A).

"Everyone knows" that politicians conceal their true motives. We tend to assume these untruths serve politicians' interests, and by extension that they vary as much as politicians' interests do. As citizens, we treat such untruths as unsystematic, if not random. But that is the wrong model. There is more insight to be had, because there is useful information in the pattern of untruths. This paper takes the view that some politicians deceive, and at least some component of the deception is systematic, a response to identifiable stimuli, with consequences that are also systematic, and hence predictable. Recognizing this difference allows us to distinguish between unintended consequences in institutional reform, which are unforeseen effects that are unsystematic, ${ }^{12}$ and instrumental incoherence. In the latter, reformers' incentives map onto the specifics of reform design via their side effects, which in turn leads to the medium- and long-term consequences that are eventually realized.

Understanding this helps us understand why institutional reforms are so popular, and why many of them are seen to fail. Some politicians sincerely design institutional reforms around the main effects those reforms are expected to have. They are likely to be judged by citizens according to policy design and implementation. But other politicians pursue reforms in service of their immediate political needs. Such policies are designed around their side effects, not their main impacts. If their main impacts disappoint, voters may feel deceived, and politicians may be ejected from office. This

\footnotetext{
$\overline{12}$ E.g., Bureaucratic problems of implementation, or geographically specific natural resource shocks.
} 
opens the door for new politicians to promise new reforms in service to different political needs, and reap new failures. The policy space for reforms that serve both voters' and politicians' interests is limited, and at times may be vacant. The danger is a grinding engine of reform that gradually degrades institutions and undermines voters' faith in democracy.

Acknowledgements We thankfully acknowledge the Leverhulme Trust and the LSE's William Robson Memorial Prize. We are grateful to Mayling Birney, Teddy Brett, Ha-Joon Chang, Lesley-Ann Daniels, Tim Dyson, Tasha Fairfield, Elliott Green, Jonathan Hartlyn, Liesbet Hooghe, Evelyne Huber, Nihal Kayali, Adnan Khan, Jelle Koedam, Gary Marks, Luigi Mendez, Roger Myerson, Anouk Rigterink, Charles Roger, Ken Shadlen, Gabriel Suchodolski, Rajesh Venugopal, Robert Wade, Borge Wietzke, and seminar participants at Cambridge, IBEI, UCLA, UNC Chapel Hill, and the LSE ID Research Seminar for their thoughtful suggestions. All remaining errors are ours.

\section{References}

Bardhan P. Decentralization of governance and development. J Econ Perspect. 2002;16:185-205.

Bardhan P, Mookherjee D, editors. Decentralization and local governance in developing countries: a comparative perspective. Cambridge: MIT Press; 2006.

Boone C. Decentralization as political strategy in West Africa. Comparative Political Studies. 2003;36(4): 355-80.

Cheema A, Mohmand S. Decentralization and inequality in Pakistan: bridging the gap? In M. Ali \& M. Saqib (Eds.), Devolution and governance: reforms in Pakistan: Oxford University Press. 2008.

Currie TE, Greenhill SJ, Gray RD, Hasegawa T, Mace R. Rise and fall of political complexity in island SouthEast Asia and Pacific. Nature. 2010;467:801-4.

Cyan M, Porter D, Sharif H, Charlton J, Hasnain Z, Manning N. Devolution in Pakistan: overview of the ADB/DfID/World Bank study. 2004.

de Condorcet M. Essai sur l'Application de l'Analyse à la Probabilité des Décisions rendues à la Pluraliste des Voix. Paris: Imprimerie Royale; 1785.

de Tocqueville A. [1835-40]. Democracy in America. P. Bradley (ed.). trans. H. Reeve. London: Everyman's library; 1994.

Diamond L, Linz JJ, Lipset SM. Politics in developing countries: comparing experiences with democracy. Boulder: Lynne Reinner; 1995.

Díaz-Cayeros A. Federalism, fiscal authority, and centralization in Latin America. Cambridge: Cambridge University Press; 2006.

Dickovick JT. Decentralization and recentralization in the developing world: comparative studies from Africa and Latin America. University Park: Pennsylvania State University Press; 2011.

Eaton K. Politics beyond the capital: the design of subnational institutions in Latin America. Stanford: Stanford University Press; 2004.

Eaton K, Kaiser K, Smoke P. The political economy of decentralization reforms: implications for aid effectiveness. Washington, DC: World Bank; 2011.

Eaton KJP, Faguet I, Harbers AH, Schakel L, Hooghe G, Marks S, Niedzwiecki S, Chapman Osterkatz, ShairRosenfield S. Measuring and theorizing regional governance. Territory, Politics, Governance. 2018;7(2): 265-283.

Faguet JP. Decentralization and popular democracy: governance from below in Bolivia. Ann Arbor: University of Michigan Press; 2012.

Faguet JP. Decentralization and governance. World Dev. 2014a;53:2-13.

Faguet JP. Can sub-national autonomy strengthen democracy in Bolivia? Publius: The Journal of Federalism. 2014b;44(1):51-81. https://doi.org/10.1093/publius/pjt020.

Faguet JP. Transformation from Below in Bangladesh: Decentralization, Local Governance, and Systemic Change. Mod Asian Stud 2017;51(6):1668-1694. https://doi.org/10.1017/S0026749X16000378.

Falletti TG. Decentralization and subnational politics in Latin America. Cambridge: Cambridge University Press; 2010.

Faguet JP, Pöschl C, editors. Is decentralization good for development? Perspectives from academics and policy makers. Oxford: Oxford University Press; 2015. 
Fischer S, editor. Rational expectations and economic policy. Chicago: University of Chicago Press; 1980.

Green E. Patronage, district creation, and reform in Uganda. Stud Comp Int Dev. 2010;45(1):83-103.

Greif A. Cultural beliefs and the organization of society: a historical and theoretical reflection on collectivist and individualist societies. J Polit Econ. 1994;102(5):912-50.

Greif A, Laitin DD. A theory of endogenous institutional change. American Political Science Review. 2004;98(4):633-52.

Grindle MS. Audacious reforms. Baltimore: Johns Hopkins University Press; 2000.

Hall PA. "Historical Institutionalism in Rationalist and Sociological Perspective." Chapter 7. In: Mahoney J, Thelen K, editors. Explaining Institutional Change: Ambiguity, Agency. Power. New York: Cambridge University Press; 2009.

Hayek F. [1939] The economic conditions of interstate federalism. Reprinted in F. Hayek. Individualism and Economic Order. Chicago: University of Chicago Press; 1948.

Hechter M. Containing nationalism. New York: Oxford University Press; 2000.

Hiskey JT, Seligson MA. Pitfalls of power to the people: decentralization, local government performance, and system support in Bolivia. Stud Comp Int Dev. 2003;37(4):64-88.

Hodgson GM, Knudsen T. Why we need a generalized Darwinism, and why generalized Darwinism is not enough. J Econ Behav Organ. 2006;61:1-19.

Horowitz DL. A democratic South Africa? Constitutional engineering in a divided society. Berkeley: University of California Press; 1991.

Hylton F, Thompson S. The roots of rebellion, I. insurgent Bolivia. NACLA Rep Am. 2007;38(3):15-9.

INE (Instituto Nacional de Estadística). Censo Nacional de Población y Vivienda. La Paz: INE; 1992.

Iversen T, Soskice D. Electoral institutions and the politics of coalitions: why some democracies redistribute more than others. American Political Science Review. 2006;100(2):165-81.

Keefer P, Narayan A, Vishwanath T. The political economy of decentralization in Pakistan. Chapter 9. In: Bardhan P, Mookerjee D, editors. Decentralization and local governance in developing countries: a comparative perspective. Cambridge: MIT; 2003.

Kohl B. Stabilizing neoliberalism in Bolivia: popular participation and privatization. Polit Geogr. 2002;21: 449-72.

Kohl B, Farthing LC. Impasse in Bolivia: neoliberal hegemony and popular resistance. London: Zed Books; 2006.

Kydland FE, Prescott EC. Rules rather than discretion: the inconsistency of optimal plans. J Polit Econ. 1977;85(3):473-92.

Levitas A. Local government reform as state building: what the polish case says about 'decentralization'. Stud Comp Int Dev. 2017;52(1):23-44.

Levy J. Tocqueville's Revenge. Cambridge: Harvard University Press; 1999.

Lewis OA, Steinmo S. How institutions evolve: evolutionary theory and institutional change. Polity. 2012;44(3):314-39.

Litvack J, Ahmad J, Bird R. Rethinking decentralization in developing countries. Washington, DC: World Bank; 1998.

Liu M, Shih V, Zhang D. The fall of the old guards: explaining decentralization in China. Stud Comp Int Dev. 2018;53(4):379-403.

Lucas R. Principles of fiscal and monetary policy. J Monet Econ. 1986;17(1):117-34.

Mahoney J, Thelen K, editors. Explaining institutional change: ambiguity, agency. Power. New York: Cambridge University Press; 2009.

Manning N, Porter D, Charlton J, Cyan M, Hasnain Z. Devolution in Pakistan - preparing for service delivery improvements. FIRSD conference paper. 2003.

Manor J. The political economy of democratic decentralization. Washington, DC: The World Bank; 1999.

Mesa CD. "Bolivia: Autonomías y pluralismo político. Un modelo condicionado por el horizonte indígena." Chapter 2. In: Zuazo M, Faguet JP, Bonifaz G, editors. 2012 Descentralización y democratización en Bolivia: La historia del Estado débil, la sociedad rebelde y el anhelo de democracia. Friedrich Ebert Stiftung: La Paz; 2012.

Mill JS. In: Williams G, editor. [1895-61]. Utilitarianism; on liberty; considerations on representative government; remarks on Bentham's philosophy. London: Everyman; 1993.

Montesquieu, Baron de (C. de Secondat). [1748] The Spirit of the Laws. trans. A. M. Cohler, B. C. Miller and H. Stone. Cambridge: Cambridge University Press. 1989.

Nagarajan HK, Binswanger-Mkhize HP, Meenakshisundaram SS. New Delhi: Foundation books/Cambridge University Press. 2015.

North D. Institutions, institutional change and economic performance. Cambridge: Cambridge University Press; 1990. 
Oates W. Fiscal Federalism. New York: Harcourt Brace; 1972.

O'Neill K. Decentralization as an electoral strategy. Comparative Political Studies. 2003;36(9):1068-91.

Patton M. Qualitative evaluation and research methods. Beverly Hills: Sage; 1990.

Pierson P. Politics in time: history, institutions, and social analysis. Princeton: Princeton University Press; 2004.

Piriou-Sall S. Decentralization and rural development: a review of evidence. Washington, DC: Manuscript; 1998.

Prud'homme R. On the dangers of decentralization. World Bank Research Observer. 1995;10:210-26.

Rogowski R. Trade and the variety of democratic institutions. Int Organ. 1987;41(2):203-23.

Rondinelli DA, GCheema GS, Nellis J. Decentralization in developing countries: a review of recent experience. World Bank Staff Working Paper No.581. Washington, DC: World Bank. 1983.

Rousseau JJ. [1762] On the social contract. R. D. Masters (ed.). trans. J. R. Masters. New York: St. Martin's Press; 1978.

Sánchez de Lozada, G, Faguet JP. Why I decentralized Bolivia, Chapter 2 in Faguet and Pöschl. 2015.

Schattschneider EE. The semisovereign people: a realist's view of democracy in America. Hinsdale: Dryden Press; 1960.

Schneider A. Decentralization: conceptualization and measurement. Stud Comp Int Dev. 2003;38(3):32-56.

Shepsle K. Studying institutions: some lessons from the rational choice approach. J Theor Polit. 1989;1:13149.

Smoke P. Fiscal decentralization in developing countries: a review of current concepts and practice. Democracy, Governance and Human Rights Programme Paper No. 2. Geneva: UNRISD. 2001.

Smoke P, Gómez EJ, Peterson GE, editors. Decentralization in Asia and Latin America. Cheltenham: Edward Elgar; 2006.

Streeck W, Thelen K, editors. Beyond continuity: institutional change in advanced political economies. Oxford: Oxford University Press; 2005.

Thelen K. Historical institutionalism in comparative politics. Annu Rev Polit Sci. 1999;2:369-404.

Tiebout CM. A pure theory of local expenditures. J Polit Econ. 1956;64:416-24.

Treisman D. The architecture of government: rethinking political decentralization. New York: Cambridge University Press; 2007.

Wallis JJ, Oates WE. Decentralization in the public sector an empirical study of state and local government. In: Rosen H, editor. Fiscal Federalism Quantitative Studies. Chicago: University of Chicago Press; 1988.

Waseem M. Democratization in Pakistan: a study of the 2002 elections. Karachi: Oxford University Press; 2006.

World Bank. Decentralization and accountability of the public sector. In: Proceedings of the annual World Bank conference on development in Latin America and the Caribbean. Washington, DC: World Bank; 1999.

Publisher's Note Springer Nature remains neutral with regard to jurisdictional claims in published maps and institutional affiliations.

Jean-Paul Faguet is Professor of the Political Economy of Development at the London School of Economics. $\mathrm{He}$ is also Chair of the Decentralization Task Force at Columbia University's Initiative for Policy Dialogue 